\title{
Role of the Goat $\mathrm{K}_{222}-\mathrm{PrP}^{\mathrm{C}}$ Polymorphic Variant in Prion Infection Resistance
}

\author{
Patricia Aguilar-Calvo, ${ }^{a}$ Juan Carlos Espinosa, ${ }^{a}$ Belén Pintado, ${ }^{b}$ Alfonso Gutiérrez-Adán, ${ }^{\mathrm{c}}$ Elia Alamillo, ${ }^{\mathrm{a}}$ Alberto Miranda, ${ }^{\mathrm{a}, \mathrm{c}}$ \\ Irene Prieto, ${ }^{a}$ Alex Bossers, ${ }^{d}$ Olivier Andreoletti, ${ }^{\text {e Juan María Torres }}{ }^{\mathrm{a}}$

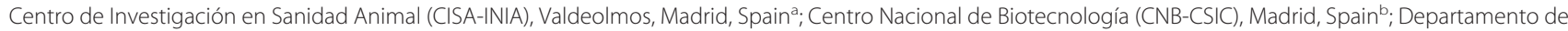 \\ Reproducción Animal, INIA, Madrid, Spainc; Central Veterinary Institute of Wageningen UR, Lelystad, The Netherlands'; INRA, UMR 1225, Interactions Hôtes Agents \\ Pathogènes, Ecole Nationale Vétérinaire de Toulouse, Toulouse Cedex, France ${ }^{\mathrm{e}}$
}

\section{ABSTRACT}

The prion protein-encoding gene (prnp) strongly influences the susceptibility of small ruminants to transmissible spongiform encephalopathies (TSEs). Hence, selective breeding programs have been implemented to increase sheep resistance to scrapie. For goats, epidemiological and experimental studies have provided some association between certain polymorphisms of the cellular prion protein $\left(\mathrm{PrP}^{\mathrm{C}}\right)$ and resistance to $\mathrm{TSEs}$. Among them, the $\mathrm{Q} / \mathrm{K}$ polymorphism at $\mathrm{PrP}^{\mathrm{C}} \operatorname{codon} 222\left(\mathrm{Q} / \mathrm{K}_{222}\right)$ yielded the most promising results. In this work, we investigated the individual effects of the $\mathrm{K}_{222}-\mathrm{PrP}^{\mathrm{C}}$ variant on the resistance/susceptibility of goats to TSEs. For that purpose, we generated two transgenic mouse lines, expressing either the $Q_{222}$ (wild type) or $K_{222}$ variant of goat $\operatorname{PrP}^{\mathrm{C}}$. Both mouse lines were challenged intracerebrally with a panel of TSE isolates. Transgenic mice expressing the wildtype $\left(Q_{222}\right)$ allele were fully susceptible to infection with all tested isolates, whereas transgenic mice expressing similar levels of the $\mathrm{K}_{222}$ allele were resistant to all goat scrapie and cattle $\mathrm{BSE}$ isolates but not to goat $\mathrm{BSE}$ isolates. Finally, heterozygous $\mathrm{K} / \mathrm{Q}_{222}$ mice displayed a reduced susceptibility to the tested panel of scrapie isolates. These results demonstrate a highly protective effect of the $\mathrm{K}_{222}$ variant against a broad panel of different prion isolates and further reinforce the argument supporting the use of this variant in breeding programs to control TSEs in goat herds.

\section{IMPORTANCE}

The objective of this study was to determine the role of the $K_{222}$ variant of the prion protein (PrP) in the susceptibility/resistance of goats to transmissible spongiform encephalopathies (TSEs). Results showed that transgenic mice expressing the goat $\mathrm{K}_{222}-\mathrm{PrP}$ polymorphic variant are resistant to scrapie and bovine spongiform encephalopathy (BSE) agents. This protective effect was also observed in heterozygous $\mathrm{Q} / \mathrm{K}_{222}$ animals. Therefore, the single amino acid exchange from $\mathrm{Q}$ to $\mathrm{K}$ at codon 222 of the cellular prion protein provides resistance against TSEs. All the results presented here support the view that the $K_{222}$ polymorphic variant is a good candidate for selective breeding programs to control and eradicate scrapie in goat herds.

crapie is an infectious neurodegenerative disease naturally affecting sheep and goats. It belongs to the group of transmissible spongiform encephalopathies (TSEs), or prion diseases, such as Creutzfeldt-Jakob disease (CJD) in humans, bovine spongiform encephalopathy (BSE) in cattle, and chronic wasting disease in cervids. TSEs are characterized by the accumulation in the central nervous system (CNS) of a pathological aberrant form $\left(\mathrm{PrP}^{\mathrm{Sc}}\right)$ of the host cellular prion protein $\left(\mathrm{PrP}^{\mathrm{C}}\right)(1)$.

Scrapie occurrence is determined mainly by the host prion protein-encoding gene ( $\operatorname{prnp})(2,3)$ and the prion strain (4), thus resulting in distinct disease phenotypes (showing differences in the $\mathrm{PrP}^{\mathrm{Sc}}$ deposition pattern, incubation period, pathogenesis, or clinical signs). Sheep and goats share the same $\operatorname{PrP}^{\mathrm{C}}$ amino acid sequence, but with a variety of polymorphisms. Sheep prnp genotypes $\mathrm{V}_{136} \mathrm{R}_{154} \mathrm{Q}_{171}$ and $\mathrm{A}_{136} \mathrm{R}_{154} \mathrm{Q}_{171}$ are associated with highlevel susceptibility to classical scrapie, while the $A_{136} R_{154} R_{171}$ genotype is linked to resistance (5-8). This information was used in some European Union member states to implement selective breeding programs in order to promote the $\mathrm{A}_{136} \mathrm{R}_{154} \mathrm{R}_{171}$ haplotype within ovine herds (9).

In goats, half a hundred polymorphisms in the open reading frame (ORF) of the prnp gene have been described (10-12), including some silent mutations, a three-octapeptide-repeat variant (13), and a nonsense mutation at codon 32 (14). Although several polymorphisms are shared by sheep and goats, to date, only some correlations between some variants of goat $\operatorname{PrP}^{\mathrm{C}}\left(\mathrm{goPrP}^{\mathrm{C}}\right)$ and susceptibility to TSE have been published. The $\mathrm{I} / \mathrm{M}_{142}$ amino acid substitution was associated with a slightly decreased risk of developing scrapie (15-17) and with prolonged incubation times after challenge with scrapie and BSE prions (18). The same effect on the incubation period was attributed to the three-repeat/glycine 102 genotype $(13,18)$. In natural outbreaks, goats carrying the $H / R_{143}$ polymorphism showed a partial decrease in their susceptibility to scrapie prions $(15,19)$. Likewise, a low susceptibility to scrapie was also linked to the $\mathrm{R} / \mathrm{H}_{154}$ and $\mathrm{R} / \mathrm{Q}_{211}$ variants of goat $\operatorname{PrP}^{\mathrm{C}}$ (15, 20 ), although the $\mathrm{R} / \mathrm{H}_{154}$ polymorphism also arose as a risk factor for goat atypical scrapie (21). In addition, other $\operatorname{PrP}^{\mathrm{C}}$ variants, such as the $\mathrm{N} / \mathrm{D}_{146}$ and $\mathrm{N} / \mathrm{S}_{146}$ polymorphisms, were linked to resistance to scrapie (22). However, the most encouraging results

Received 1 October 2013 Accepted 10 December 2013

Published ahead of print 18 December 2013

Editor: B. W. Caughey

Address correspondence to Juan María Torres, jmtorres@inia.es.

Copyright @ 2014, American Society for Microbiology. All Rights Reserved.

doi:10.1128/JVI.02074-13 
are those related to the $\mathrm{Q} / \mathrm{K}_{222}$ polymorphism. The absence or marked underrepresentation of scrapie-positive goats expressing the $\mathrm{K}_{222}$ variant in numerous herds from different countries (11, $12,15,20,22-25)$ suggests that the $\mathrm{K}_{222}-\mathrm{PrP}^{\mathrm{C}}$ variant strongly influences goat susceptibility to TSE agents. Recently, heterozygous $\mathrm{Q} / \mathrm{K}_{222}$ goats were reported to show a strong resistance to classical scrapie after intracerebral (i.c.) inoculation (26), as also reported in the accompanying article by Lacroux et al. (27). This evidence should be reinforced by experimental data, but the large number of genetic variants harbored in the goat prnp gene hinders in vivo determination of the individual effects of the $\mathrm{K}_{222}-\mathrm{PrP}^{\mathrm{C}}$ variant in this matter.

In this work, we analyzed the role of the $\mathrm{K}_{222}$ variant of goat $\mathrm{PrP}^{\mathrm{C}}$ in the susceptibility to prion infection. For that purpose, two transgenic mouse lines, one expressing the wild-type (wt) goat $\operatorname{PrP}^{\mathrm{C}}$ sequence and another expressing the same $\operatorname{PrP}^{\mathrm{C}}$ sequence, but with a single amino acid exchange from $\mathrm{Q}$ to $\mathrm{K}$ at codon 222, were generated. Both mouse lines were challenged i.c. with a panel of TSE isolates, and their susceptibilities were assessed and then compared.

\section{MATERIALS AND METHODS}

Ethics statement. Animal experiments were carried out in strict accordance with the recommendations in the guidelines of European Community Council Directive 86/609/EEC, and all efforts were made to minimize suffering. Experiments were approved by the Committee on the Ethics of Animal Experiments of INIA (permit number CEEA2009/003).

Transgenic mice. The procedures used to generate transgene constructs have been described elsewhere (28). Briefly, the ORF of goat wt prnp was isolated by PCR amplification and sequenced, and the sequence was identical to the goat prnp sequence previously reported (GenBank accession number AF117316). The primers used created an XhoI restriction enzyme site adjacent to the translation start and stop sites of the goat PrP gene ORF (5'-CTCGAGATCATGGTGAAAAGCCACATAGG C-3' and $3^{\prime}$-CTCGAGCTATCCTACTATGAGAAAAATGAG-5', respectively). The PCR fragment was subcloned into the pGEM-T Easy vector system (Promega) following the manufacturer's instructions. The expression vector MoPrP.Xho (29) was used for the production of transgenic mice. This vector contains the murine $\operatorname{PrP}(\mathrm{muPrP})$ promoter, exon 1 , intron 1, exon 2, and 3'-untranslated sequences. The PrP ORF fragment was excised from the pGEM-T vector by using the restriction enzyme XhoI and was inserted into the MoPrP.Xho expression vector (29), also digested with the XhoI enzyme, resulting in the plasmid pMo-GoPrP.Xho. This plasmid was mutated to generate $\mathrm{K}_{222}$-PrP plasmid (pMo-GoK ${ }_{222}$-PrP.Xho) by using a QuikChange II XL kit (Stratagene, CA) with specific oligonucleotides (5'-GTGCATCACCCAGTACAAGAGAGAATCCCAGGC-3' and 3'-GCC TGGGATTCTCTCTTGTACTGGGTGATGCAC-5' ), following the procedures described by the manufacturer. The MoPrP.Xho expression vector contains the murine wt prnp gene, including the murine prnp promoter, exon 1 , intron 1 , exon 2 , and $3^{\prime}$-untranslated sequences, but not intron 2 and the murine PrP ORF.

Transgenic mouse lines were generated as previously described (28). Briefly, transgenes were excised from their expression vectors (pMoGoPrP.Xho and pMo-GoK ${ }_{222}$-PrP.Xho) by use of the restriction endonuclease NotI, leading to DNA fragments of approximately $12 \mathrm{~kb}$. DNAs were then purified using sodium chloride gradients as previously described (30) and resuspended in TE (10 mM Tris, pH 7.4, 0.1 mM EDTA) at a final concentration of 2 to $6 \mathrm{ng} / \mathrm{ml}$. Finally, DNAs were microinjected into pronuclear-stage embryos collected from superovulated B6CBAF1 females mated with 129/Ola males carrying a null mutation in their endogenous PrP gene (31).

DNAs were extracted from founders' tail biopsy specimens by use of an Extract-N-Amp tissue PCR kit (Sigma-Aldrich) following the manufacturer's instructions. The presence of the goat transgene in these founders was identified by PCR amplification using specific primers for mouse
PrP exon 2 and the goat PrP ORF. The primers used were $5^{\prime}$-CATTCTG CCTTCCTAGTGGTACC- $3^{\prime}$ and $5^{\prime}$-GCTTGTTCCACTGACTGTGGC$3^{\prime} . \mathrm{muPrP}^{+/-} \mathrm{goPrP}^{+/-}$founders were backcrossed with homozygous PrP null animals (muPrP ${ }^{-1-}$ ) to obtain mice homozygosis for the null mutation $\left(\mathrm{muPrP}^{-1-} \mathrm{goPrP}^{+-}\right)$. The absence of the murine PrP ORF in the transgenic mice thus generated was confirmed by PCR amplification using the primers $5^{\prime}$-ATGGCGAACCTTGGCTACTGGC- ${ }^{\prime}$ and $5^{\prime}$-GAT TATGGGTACCCCCTCCTTGG-3'.

Analysis of $\operatorname{PrP}^{\mathrm{C}}$ expression in transgenic mice. Whole brains from either mice or goats were homogenized in extraction buffer ( $0.5 \% \mathrm{NP}-40$, $1 \%$ sodium deoxycholate, $10 \mathrm{mM}$ EDTA in phosphate-buffered saline [PBS], pH 7.4, with Complete protease inhibitor cocktail [Roche]). Samples were precleared by centrifugation at $2,000 \times g$ for $5 \mathrm{~min}$, after which an equal volume of $2 \times$ SDS reducing sample loading buffer was added to all samples, and each one was boiled for 5 min before being loaded onto an SDS- $12 \%$ polyacrylamide gel. For immunoblotting experiments, the monoclonal antibodies (MAbs) FH11 (32) and 12B2 (33) were used at a concentration of $1 \mu \mathrm{g} / \mathrm{ml}$. FH11 recognizes the goat PrP amino-terminal region (amino acids 23 to 85 ), and $12 \mathrm{~B} 2$ recognizes the ${ }_{93} \mathrm{WGQGG}_{97}$ epitope of the goat PrP sequence. Immunocomplexes were detected using horseradish peroxidase-conjugated anti-mouse IgG. Immunoblots were developed with enhanced chemiluminescence.

Transmission studies. Transgenic mice were challenged with a panel of TSE agents, including cattle BSE, goat BSE, and different goat scrapie isolates (see Table 1 for isolate information). Inocula were prepared from infected brain tissues as 10\% (wt/vol) homogenates in 5\% glucose.

Groups of 6 to 9 individual identified animals (6 to 7 weeks old) were anesthetized and inoculated intracerebrally with $20 \mu \mathrm{l}$ of $10 \%$ brain homogenate in the right parietal lobe, using a 25 -gauge disposable hypodermic needle. As a control, 6 or 7 animals of each line were inoculated with healthy goat brain to discard the possibility of appearance of a spontaneous prion disease. Mice were observed daily and their neurological status assessed twice a week. When the progression of the disease was evident, or at the end of their life span ( $\approx 650$ days), mice were euthanized for ethical reasons. During necropsy, the brain was harvested at $-20^{\circ} \mathrm{C}$ for determination of the presence of proteinase K-resistant $\operatorname{PrP}\left(\mathrm{PrP}^{\mathrm{res}}\right)$ by Western blotting (WB). Survival time was expressed as the mean number of survival days postinoculation (dpi) for all the $\mathrm{PrP}^{\text {res }}$-positive mice, with the standard error included. Attack rate was determined as the proportion of $\mathrm{PrP}^{\text {res }}$-positive mice among all the mice inoculated.

Western blotting. A total of $175 \mathrm{mg}$ of brain tissue was homogenized in $5 \%$ glucose in distilled water in grinding tubes (Bio-Rad) and adjusted to $10 \%(\mathrm{wt} / \mathrm{vol}$ ) by using a TeSeETM Precess $48 \mathrm{TM}$ homogenizer (BioRad) following the manufacturer's instructions. To determine the presence of PrP ${ }^{\text {res }}$ in transgenic mouse brains, $100 \mu$ l of $10 \%$ brain homogenate was analyzed by Western blotting as previously described (34). For immunoblotting, membranes were incubated with the Sha31 MAb (35), which recognizes the ${ }_{148}$ YEDRYYRE $_{155}$ epitope of the goat PrP sequence. Immunocomplexes were detected with horseradish peroxidase-conjugated anti-mouse IgG (Amersham Pharmacia Biotech) after incubating the membranes for $1 \mathrm{~h}$, and immunoreactivity was visualized by chemiluminescence with ECL Plus (GE Healthcare Amersham Biosciences).

Histopathological analysis. All procedures concerning the histopathological analysis of infected mouse brains were performed as previously described (36). Brain samples were immediately fixed in neutralbuffered $10 \%$ formalin (4\% 2-formaldehyde) during mouse necropsy and paraffin embedded later. After deparaffinization, $2-\mu \mathrm{m}$-thick tissue slices were stained with hematoxylin and eosin. Lesion profiles of the brains were established following the standard method of Fraser and Dickinson (37). Paraffin-embedded tissue (PET) blots and immunohistochemistry (IHC) were conducted as described by Andreoletti et al. $(38,39)$.

\section{RESULTS}

Goat $\operatorname{PrP}^{\mathrm{C}}$ expression in transgenic mice. Several mouse lines (founders) were obtained for each transgene $\left(\mathrm{Q}_{222}-\mathrm{PrP}^{\mathrm{C}}\right.$ or $\mathrm{K}_{222^{-}}$ 
TABLE 1 Description of the different isolates used in this work

\begin{tabular}{|c|c|c|c|c|}
\hline Isolate & Origin (local code) & Goat PrP genotype ${ }^{a}$ & Description (reference) & Supplier ${ }^{b}$ \\
\hline Goat-BSE1 & France (CH0064) & $\mathrm{I}_{136} \mathrm{Q}_{154} \mathrm{~S}_{240} / \mathrm{I}_{136} \mathrm{R}_{154} \mathrm{~S}_{240}$ & $\begin{array}{l}\text { Isolate from a terminally ill goat intracerebrally inoculated } \\
\text { with Ca-BSE isolate }\end{array}$ & INRA \\
\hline Goat-BSE2 & France (CH1075) & $\mathrm{I}_{136} \mathrm{R}_{154} \mathrm{~S}_{240} / \mathrm{I}_{136} \mathrm{R}_{154} \mathrm{P}_{240}$ & $\begin{array}{l}\text { Isolate from a terminally ill goat intracerebrally inoculated } \\
\text { with Ca-BSE isolate }\end{array}$ & INRA \\
\hline Sheep-BSE & France $\left(\mathrm{ARQ}_{0}\right)$ & wt & $\begin{array}{l}\text { Isolate from a pool of terminally ill ARQ/ARQ sheep } \\
\text { inoculated with Ca-BSE isolate (45) }\end{array}$ & INRA \\
\hline Ca-BSE & France (139) & & BSE isolate from a naturally infected cow (45) & INRA \\
\hline Goat-Sc I3 & Italy $(121429 / 1 / 1)$ & wt & Classical scrapie isolate from a naturally infected goat & IZSTO \\
\hline Goat-Sc I9 & Italy $(85792 / 1 / 1)$ & $\mathrm{wt} ; \mathrm{S} / \mathrm{P}_{240}$ & Classical scrapie isolate from a naturally infected goat & IZSTO \\
\hline Goat-Sc S2 & Spain $(C-163)$ & wt; $\mathrm{S} / \mathrm{P}_{240}$ & Classical scrapie isolate from a naturally infected goat & UNIZAR \\
\hline Goat-Sc S3 & Spain (C-645) & wt 240 & Classical scrapie isolate from a naturally infected goat & UNIZAR \\
\hline Healthy goat brain & & wt & Brain from a noninfected goat & INRA \\
\hline
\end{tabular}

${ }^{a}$ The wild-type (wt) goat prion protein genotype is $\mathrm{A}_{136} \mathrm{R}_{154} \mathrm{P}_{240} / \mathrm{A}_{136} \mathrm{R}_{154} \mathrm{P}_{240}$.

${ }^{b}$ INRA, French National Institute for Agricultural Research, Nouzilly, France; IZSTO, Istituto Zooprofilattico Sperimentale del Piemont, Italy; UNIZAR, Universidad de Zaragoza, Spain.

$\left.\operatorname{PrP}^{\mathrm{C}}\right)$. Founder animals also expressing the endogenous murine prnp gene (muprnp ${ }^{+/-}$goprnp ${ }^{+/-}$) were crossed with prnp null mice (muprnp ${ }^{-1-}$ ) to obtain transgene-hemizygous lines in a murine $p r n p$ null background (muprnp $p^{-I-}$ goprnp ${ }^{+-}$). The absence of murine prnp was determined by PCR using specific primers (data not shown). The $\mathrm{PrP}^{\mathrm{C}}$ expression levels in brain homogenates were then determined by serial dilution and Western blotting using the 12B2 MAb and were compared with the $\operatorname{PrP}^{\mathrm{C}}$ levels found in goat brain homogenates. The $\mathrm{Q}_{222}-\mathrm{Tg} 501$ and $\mathrm{K}_{222^{-}}$ Tg516 lines were selected based on the fact that they had $\mathrm{PrP}^{\mathrm{C}}$ expression levels in the brain similar to those in goats (Fig. 1). In addition, both $\mathrm{Q}_{222}-\mathrm{PrP}^{\mathrm{C}}$ and $\mathrm{K}_{222}-\mathrm{PrP}^{\mathrm{C}}$ expressed in brains of transgenic mice showed electrophoretic profiles similar to that observed for $\mathrm{PrP}^{\mathrm{C}}$ from goat brain (Fig. 1). Finally, the hemizygous $\mathrm{Q}_{222}$-Tg501 and $\mathrm{K}_{222}$-Tg516 mouse lines were used for transmission studies.

Transgenic mice expressing the $\mathrm{K}_{222}$-PrP variant are resistant to a broad panel of goat scrapie isolates. The $\mathrm{Q}_{222}$ - $\mathrm{Tg} 501$ mouse line, expressing wild-type goat $\mathrm{PrP}^{\mathrm{C}}$, was susceptible to all inoculated scrapie isolates. Intracerebrally challenged animals displayed a $100 \%$ attack rate, and mean survival times ranged from 250 to 650 dpi (Table 2). No differences were observed between the electrophoretic profiles of $\mathrm{PrP}^{\mathrm{res}}$ in the inoculated isolates and

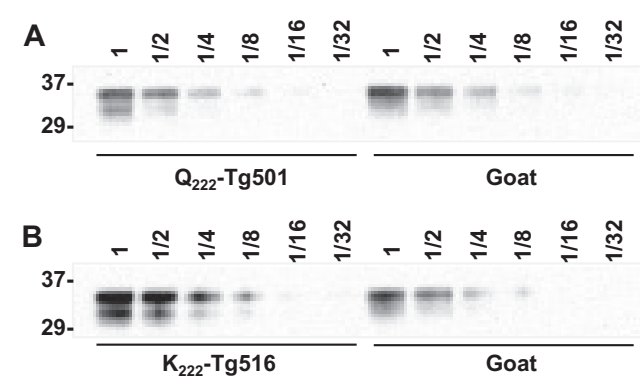

FIG 1 Brain $\operatorname{PrP}^{\mathrm{C}}$ expression in hemizygous $\mathrm{Q}_{222}-\mathrm{Tg} 501$ (A) and $\mathrm{K}_{222}$ - $\mathrm{Tg} 516$ (B) mouse lines in comparison with that in goat brain. Immunoblotting of $\mathrm{PrP}^{\mathrm{C}}$ was performed with the 12B2 MAb. Direct samples (10\% brain homogenates) and $1 / 2$ serial dilutions were loaded onto $12 \%$ Bis-Tris gels. The figure illustrates a representative set of data for three independent experiments. Relative molecular masses $(\mathrm{kDa})$ are indicated on the left. those of the $\operatorname{PrP}^{\text {res }}$ present in the brains of challenged $\mathrm{Q}_{222}-\mathrm{Tg} 501$ mice (Fig. 2).

In contrast, none of the $\mathrm{K}_{222}$-Tg516 mice succumbed to inoculation with any of the scrapie isolates (Table 2). These animals were sacrificed at $650 \mathrm{dpi}$, without clinical signs, and were scored $\mathrm{PrP}^{\text {res }}$ negative in the brain by Western blotting. The absence of $\mathrm{PrP}^{\text {res }}$ in the brain was confirmed by either IHC or PET blotting. These animals exhibited some vacuolation, mainly at the level of the dorsal medulla and the mesencephalic tegmentum. However, this vacuolation was also observed in the same areas in old $\mathrm{Q}_{222}-\mathrm{Tg} 501$ and $\mathrm{K}_{222}$-Tg516 mice inoculated with healthy goat brain. In contrast, all the infected $\mathrm{Q}_{222}$ Tg501 mice displayed $\mathrm{PrP}^{\text {res }}$ deposits in the brain which were accompanied by histopathological alterations characteristic of prion infection (data not shown).

It is important that the $\mathrm{Q}_{222}-\mathrm{Tg} 501$ and $\mathrm{K}_{222}-\mathrm{Tg} 516$ mouse lines, both expressing similar amounts of $\mathrm{PrP}^{\mathrm{C}}$ in the brain, differ only in the $\mathrm{Q} / \mathrm{K}_{222}$ substitution in the $\operatorname{PrP}^{\mathrm{C}}$ sequence, thus demonstrating that this single amino acid exchange is the only muta-

TABLE 2 Transmission of a panel of prion isolates to $\mathrm{Q}_{222}$-Tg501, $\mathrm{K}_{222^{-}}$ $\mathrm{Tg} 516$, and heterozygous $\mathrm{Q} / \mathrm{K}_{222}$ mice

\begin{tabular}{llll}
\hline & \multicolumn{3}{l}{ Mean survival time (days) \pm SEM $\left(n / n_{0}\right)^{a}$} \\
\cline { 2 - 4 } Isolate & $\begin{array}{l}\mathrm{Q}_{222}-\mathrm{Tg} 501 \\
\text { mice }\left(\mathrm{Q}_{222} /-\right)\end{array}$ & $\begin{array}{l}\mathrm{K}_{222}-\mathrm{Tg} 516 \\
\text { mice }\left(\mathrm{K}_{222} /-\right)\end{array}$ & $\begin{array}{l}\text { Tg501 } \times \text { Tg516 } \\
\text { mice }\left(\mathrm{Q} / \mathrm{K}_{222}\right)\end{array}$ \\
\hline Goat-BSE1 & $497 \pm 31(5 / 5)$ & $519 \pm 42(5 / 5)$ & $533 \pm 44(5 / 5)$ \\
Goat-BSE2 & $484 \pm 34(7 / 7)$ & $478 \pm 31(4 / 4)$ & $470 \pm 14(5 / 5)$ \\
Sheep-BSE & $485 \pm 62(7 / 7)$ & $418 \pm 11(4 / 4)$ & $\mathrm{ND}$ \\
Ca-BSE & $583 \pm 57(6 / 6)$ & $>650(0 / 6)$ & $617 \pm 47(5 / 5)$ \\
Ca-BSE/Tg501 & $326 \pm 26(6 / 6)$ & $434 \pm 30(5 / 5)$ & $\mathrm{ND}$ \\
Goat-Sc F10 & $465 \pm 19(7 / 7)$ & $>650(0 / 5)$ & $>650(6 / 6)$ \\
Goat-Sc F2 & $250 \pm 36(4 / 4)$ & $>650(0 / 7)$ & $630 \pm 26(5 / 6)$ \\
Goat-Sc I3 & $659 \pm 10(5 / 5)$ & $>650(0 / 5)$ & $>650(0 / 6)$ \\
Goat-Sc I9 & $600 \pm 43(5 / 5)$ & $>650(0 / 5)$ & $\mathrm{ND}$ \\
Goat-Sc S2 & $449 \pm 62(9 / 9)$ & $>650(0 / 6)$ & $>650(0 / 6)$ \\
Goat-Sc S3 & $298 \pm 22(6 / 6)$ & $>650(0 / 6)$ & $\mathrm{ND}$ \\
Healthy goat brain & $>650(0 / 6)$ & $>650(0 / 6)$ & $>650(0 / 6)$
\end{tabular}

${ }^{a} n / n_{0}$, number of diseased, $\operatorname{PrP}^{\text {res }}$-positive animals/number of inoculated animals. ND, no data.

${ }^{b}$ Isolate from a pool of terminally ill wt Tg501 mice inoculated with the Ca-BSE isolate. 


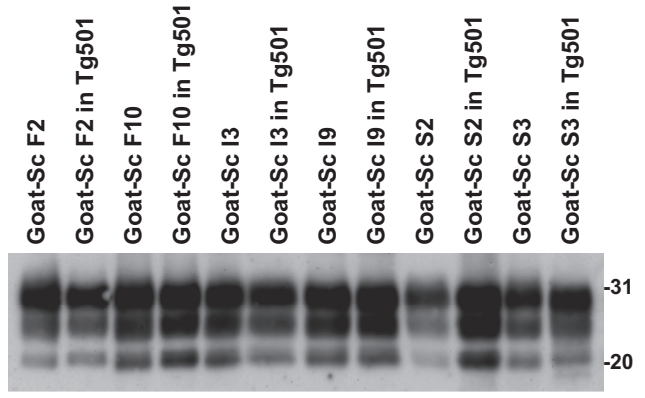

FIG $2 \mathrm{PrP}^{\mathrm{res}}$ of goat scrapie isolates both before and after transmission in $\mathrm{Q}_{222}$-Tg501 mice. Immunoblots show brain $\mathrm{PrP}^{\text {res }}$ detected with the Sha31 MAb. Similar quantities of $\mathrm{PrP}^{\text {res }}$ were loaded for adequate comparison. Molecular masses $(\mathrm{kDa})$ are shown on the right.

tion responsible for the differential susceptibility/resistance to scrapie observed between these mouse lines.

None of the $\mathrm{Q}_{222}-\mathrm{Tg} 501$ or $\mathrm{K}_{222}$-Tg516 mice inoculated with healthy brain samples succumbed to disease (Table 2). They were euthanized at the end of their life span (650 dpi), without either clinical signs or $\mathrm{PrP}^{\mathrm{res}}$ in the brain.

Transgenic mice expressing the $\mathrm{K}_{222}$-PrP variant are resistant to cattle BSE but not to goat or sheep BSE. Both the $\mathrm{Q}_{222^{-}}$ $\operatorname{Tg} 501$ and $\mathrm{K}_{222}$ - $\operatorname{Tg} 516$ mouse lines were fully susceptible (100\% attack rate) to goat and sheep BSE isolates, displaying similar mean survival times ranging from 400 to 500 dpi (Table 2). However, inoculation of cattle BSE isolates into $\mathrm{Q}_{222}$ - Tg501 and $\mathrm{K}_{222^{-}}$ Tg516 mice produced markedly different results. While $\mathrm{Q}_{222^{-}}$ Tg501 mice showed a 100\% attack rate and a survival time of $583 \pm 57 \mathrm{dpi}, \mathrm{K}_{222}$-Tg516 mice were sacrificed at the end of their life span (650 dpi), without either clinical signs or $\mathrm{PrP}^{\mathrm{res}}$ in the brain (Table 2). Moreover, $\mathrm{K}_{222}$-Tg516 mice were totally susceptible to the cattle BSE agent passaged in $\mathrm{Q}_{222}$-Tg501 mice, with a mean survival time of $434 \pm 30$ dpi.

Western blot analysis of brain $\mathrm{PrP}^{\text {res }}$ in goat BSE isolates revealed a typical $\mathrm{PrP}^{\text {res }}$ banding pattern characterized by small fragments (19-kDa fragment for the aglycosylated band) and prominent diglycosylated species. This pattern was indistinguishable from those observed for both $\mathrm{Q}_{222}$-Tg501 and $\mathrm{K}_{222}$-Tg516 mice infected with goat or sheep BSE isolates. Moreover, an identical $\mathrm{PrP}^{\text {res }}$ banding pattern was observed for $\mathrm{Q}_{222}$-Tg501 mice inoculated with cattle BSE isolates (Fig. 3).

Histopathological analysis confirmed the absence of both $\mathrm{PrP}^{\text {res }}$ deposits and spongiform changes in the brains of all $\mathrm{K}_{222^{-}}$ Tg516 mice inoculated with cattle BSE isolates. However, when these mice were infected with goat BSE isolates, they exhibited $\mathrm{PrP}^{\text {res }}$ deposition patterns and lesion profiles similar to those observed in $\mathrm{Q}_{222}$-Tg501 mice infected with either cattle or goat BSE isolates (data not shown).

Altogether, these results suggest a low transmission barrier to cattle BSE in transgenic mice expressing wild-type $\left(\mathrm{Q}_{222}\right)$ goat $\operatorname{PrP}^{\mathrm{C}}$. Conversely, the $\mathrm{K}_{222}$ amino acid substitution seemed to give rise to a transmission barrier that limited the propagation of cattle BSE prions. Nevertheless, this transmission barrier was abolished if the isolate was previously passaged in a wt goat $\operatorname{PrP}^{\mathrm{C}}$-expressing host (sheep, goat, or $\mathrm{Q}_{222}$-Tg501 mouse) (Table 2).

Heterozygous $\mathrm{Q} / \mathrm{K}_{222}$ mice show lower attack rates and/or longer survival times depending on the inoculated isolate. To accurately determine the role of the $\mathrm{K}_{222}$-PrP variant in goat resis-

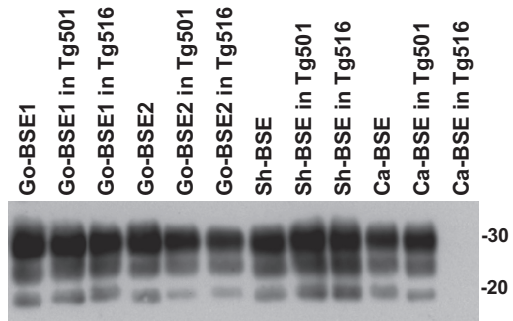

FIG $3 \mathrm{PrP}^{\mathrm{res}}$ of BSE isolates before and after transmission in either $\mathrm{Q}_{222}$ Tg501 or $\mathrm{K}_{222}$-Tg516 mice. Immunoblots show brain $\mathrm{PrP}^{\text {res }}$ detected with the Sha31 MAb. Similar quantities of $\mathrm{PrP}^{\text {res }}$ were loaded for adequate comparison. Molecular masses $(\mathrm{kDa})$ are shown on the right.

tance/susceptibility to TSEs, $\mathrm{K}_{222}$-Tg516 mice were crossbred with $\mathrm{Q}_{222}$-Tg501 mice to generate heterozygous $\left(\mathrm{Q} / \mathrm{K}_{222}\right)$ mice. These animals were inoculated intracerebrally with the same panel of TSE isolates used previously (Table 2). Heterozygous Q/K $\mathrm{K}_{222}$ animals were resistant to the Goat-Sc I3 and Goat-Sc S2 isolates. These animals were sacrificed at $650 \mathrm{dpi}$, without having shown clinical signs, and no detectable $\mathrm{PrP}^{\mathrm{res}}$ was found in their brains by $\mathrm{WB}, \mathrm{IHC}$, or PET blotting. However, $\mathrm{Q} / \mathrm{K}_{222}$ mice succumbed to infection with the Goat-Sc F2 isolate, displaying a reduced attack rate $(83.3 \%)$ and longer survival times than those observed in $\mathrm{Q}_{222}$-Tg501 mice. Moreover, $\mathrm{Q} / \mathrm{K}_{222}$ mice challenged with the Goat-Sc F10 isolate were also sacrificed at $650 \mathrm{dpi}$, without clinical signs, but $\mathrm{PrP}^{\text {res }}$ was detected in their brains (Table 2). Taken together, these results suggest that in heterozygous $\mathrm{Q} / \mathrm{K}_{222}$ mice, the $\mathrm{K}_{222}-\mathrm{PrP}^{\mathrm{C}}$ variant interferes with the replication of all tested scrapie agents.

When inoculated with the cattle BSE agent, heterozygous $\mathrm{Q} / \mathrm{K}_{222}$ animals showed prolonged survival times compared to $\mathrm{Q}_{222}$-Tg501 mice (Table 2). However, goat BSE isolates displayed similar transmission features in all transgenic mouse models challenged $\left(\mathrm{Q}_{222}\right.$-Tg501, $\mathrm{K}_{222}$-Tg516, and $\mathrm{Q} / \mathrm{K}_{222}$ mice), independent of the expressed $\mathrm{PrP}^{\mathrm{C}}$ variant, thus indicating low or nonexistent interference of the $\mathrm{K}_{222}-\mathrm{PrP}^{\mathrm{C}}$ variant with BSE agent replication.

Histopathological studies confirmed the presence of $\mathrm{PrP}^{\text {res }}$ and spongiform changes in the brains of heterozygous $\mathrm{Q} / \mathrm{K}_{222}$ mice infected with Goat-Sc F2, Goat-Sc F10, and goat and cattle BSE isolates. $\mathrm{PrP}^{\mathrm{res}}$ deposits and vacuolation profiles in these mice were similar but not identical to those determined for $\mathrm{Q}_{222}$-Tg501 mice infected with the same isolates (data not shown). However, we cannot exclude the possibility that these slight differences were linked to the old age of $\mathrm{Q} / \mathrm{K}_{222}$ mice, since they displayed longer survival times than those of $\mathrm{Q}_{222^{-}}$ Tg501 mice. Further passages are necessary to make a conclusion on this point.

\section{DISCUSSION}

In this study, we use a transgenic mouse model to assess the role of the $\mathrm{K}_{222}-\mathrm{PrP}^{\mathrm{C}}$ variant in the resistance/susceptibility of goats to TSEs. For that purpose, we generated two transgenic mouse lines, expressing either the wt $\left(\mathrm{Q}_{222}\right.$-Tg501) or the $\mathrm{K}_{222}$ variant $\left(\mathrm{K}_{222^{-}}\right.$ $\mathrm{Tg} 516)$ of goat $\mathrm{PrP}^{\mathrm{C}}$. Both mouse lines expressed similar amounts of $\mathrm{PrP}^{\mathrm{C}}$ and were challenged intracerebrally with a panel of prion isolates.

When TSE agent transmission efficiency was assessed in $\mathrm{Q}_{222}{ }^{-}$ Tg501 mice, these animals showed high-level susceptibility (100\% 
attack rate) to all the tested scrapie and BSE isolates. $\mathrm{PrP}^{\mathrm{res}}$ profiles in Western blots of all scrapie and BSE isolates were not altered after passage in these $\mathrm{Q}_{222}$-Tg501 mice (Fig. 2 and 3). Goat BSE isolates displayed a weak decrease in survival times compared with cattle BSE isolates, confirming the low transmission barrier of goats to cattle BSE previously reported for experimentally challenged goats (40). According to these data, we propose $\mathrm{Q}_{222^{-}}$ Tg501 transgenic mice expressing wild-type goat $\operatorname{PrP}^{\mathrm{C}}$ as a valuable model for both studying the susceptibility/resistance of small ruminants to TSEs and characterizing TSE strains affecting these species.

In contrast to the high-level susceptibility of $\mathrm{Q}_{222}$-Tg501 mice, $\mathrm{K}_{222}$-Tg516 mice were fairly resistant to all the classical scrapie isolates inoculated, independent of their origin or $\mathrm{PrP}^{\mathrm{res}}$ signature. Since $\mathrm{Q}_{222}$-Tg501 mice and $\mathrm{K}_{222}$-Tg516 mice express exactly the same $\operatorname{PrP}^{\mathrm{C}}$ sequence, except for the $\mathrm{Q} / \mathrm{K}_{222}$ amino acid substitution, and have similar $\operatorname{PrP}^{\mathrm{C}}$ expression levels, we can assume that the lack of transmission efficiency of classical scrapie is linked to the $\mathrm{K}_{222}$ amino acid. This conclusion is consistent with the results reported in the accompanying article by Lacroux et al. (27) and previous epidemiological studies carried out in different European goat scrapie outbreaks where the $\mathrm{K}_{222}-\mathrm{PrP}^{\mathrm{C}}$ variant was detected only in healthy goats $(12,15,23,24)$. Taken together, these results suggest that the $K_{222}$ variant of goat $\operatorname{PrP}^{C}$ is strongly resistant to a wide range of classical scrapie strains.

On the other hand, heterozygous $\mathrm{Q} / \mathrm{K}_{222}$ mice were clearly more resistant to the different scrapie isolates than $\mathrm{Q}_{222}-\mathrm{Tg} 501$ mice. These results support the contention that the $\mathrm{K}_{222}-\mathrm{PrP}^{\mathrm{C}}$ variant provides a dominant negative effect over the wild-type $\mathrm{PrP}^{\mathrm{C}}$ sequence. This phenomenon is consistent with the stone fence model (41), which predicts that for a given TSE agent, the incorporation of a conversion-incompetent $\operatorname{PrP}^{\mathrm{C}}$ variant will interfere with wild-type $\mathrm{PrP}^{\mathrm{Sc}}$ replication, resulting in a lower efficacy of prion propagation. This decreased propagation efficacy would result in reduced attack rates and/or prolonged survival times, as shown in our study, and could explain the limited epidemiological evidence linking scrapie with the $\mathrm{K}_{222}$ allele $(11,15,22)$.

BSE transmission experiments showed that mice expressing the $\mathrm{K}_{222}-\mathrm{PrP}^{\mathrm{C}}$ variant $\left(\mathrm{K}_{222}-\mathrm{Tg} 516\right.$ mice) were resistant to cattle BSE but not to goat BSE or sheep BSE isolates (Table 2). The failure of the cattle BSE isolates to be transmitted in $\mathrm{K}_{222}-\mathrm{PrP}^{\mathrm{C}}$ mice can be explained by the dual influence of both the $\operatorname{PrP}^{\mathrm{C}}$ sequence differences in prion cross-species transmission $(2,3)$ and the effect of the $\mathrm{Q} / \mathrm{K}_{222}$ amino acid substitution. In this sense, the effect of the $\mathrm{PrP}^{\mathrm{C}}$ primary sequence of the donor (bovine) is not strong enough to avoid cattle BSE replication in goat wt $\mathrm{Q}_{222^{-}}$ Tg501 mice. However, after the $\mathrm{Q} / \mathrm{K}_{222}$ substitution in $\mathrm{K}_{222}-\mathrm{Tg} 516$ mice, the cattle BSE agent is unable to replicate. This view is fully consistent with the fact that $\mathrm{K}_{222}$-Tg516 mice were susceptible to BSE only after passage in goats or $\mathrm{Q}_{222}$-Tg501 mice (Table 2). Therefore, the transmission barrier toward the BSE agent is complex, being modulated not only by the $\mathrm{K}_{222}$ allele but also by other determinants, such as the PrP amino acid differences between host and donor (goats versus cattle). Interestingly, this transmission barrier was abolished when the $\mathrm{K}_{222}-\mathrm{PrP}^{\mathrm{C}}$ variant was present in heterozygosis, indicating that for $\mathrm{BSE}$, the $\mathrm{K}_{222}$ amino acid substitution does not interfere with the conversion of wild-type $\mathrm{Q}_{222^{-}}$ $\operatorname{PrP}^{\mathrm{C}}$ into $\operatorname{PrP}^{\mathrm{Sc}}$.
An inhibitory effect on prion replication of equivalent $K_{222}$ variants has also been described for other species. The human $\mathrm{K}_{219}-\mathrm{PrP}^{\mathrm{C}}$ allele (homologous to the codon 222 allele in goat $\mathrm{PrP}^{\mathrm{C}}$ ) was reported to protect humans against Creutzfeldt-Jakob disease (42), while the equivalent $\mathrm{K}_{218}$ variant of mouse $\operatorname{PrP}^{\mathrm{C}}$ significantly reduced the fibril aggregation kinetics and generated non-proteinase K-resistant $\operatorname{PrP}(43)$. A plausible explanation for this inhibitory effect could be the insertion of an additional positive charge at codon 222, provided by the lysine amino acid $(\mathrm{K})$, thus interfering with the $\mathrm{PrP}^{\mathrm{C}}-\mathrm{PrP}^{\mathrm{Sc}}$ interaction and resulting in abolished or low conversion rates of $\operatorname{PrP}^{\mathrm{Sc}}(44)$. All these considerations suggest that codon 222 must play an important role in $\mathrm{PrP}^{\mathrm{C}}$ conformation and point it out as a target for future TSE studies.

The use of transgenic mice in our transmission studies allowed us to pinpoint the $\mathrm{Q} / \mathrm{K}_{222}$ amino acid substitution as the unique mutation responsible for the observed resistance to TSEs, excluding other genetic factors. In addition, the intracerebral inoculation route provided the best scenario for prion replication, as the inoculum was placed directly in the target tissue. Therefore, although our procedure mimics neither the natural route of scrapie infection nor the complex pathogenesis involving prion replication in peripheral tissues, our results offer solid arguments supporting the hypothesis that the $\mathrm{K}_{222}$ variant of goat $\operatorname{PrP}^{\mathrm{C}}$ provides strong resistance against a wide range of classical scrapie isolates and reinforce the view that the $\mathrm{K}_{222}$ allele is a good candidate for the development of breeding programs for resistance against scrapie in commercial goat populations.

\section{ACKNOWLEDGMENTS}

This work was supported by grants from the Spanish Ministerio de Ciencia e Innovación (AGL2009-11553-C02-02 and AGL2012-37988-C04-04) and by European Union projects (FOOD-CT-2006-36353, GoatBSE, and ERA-NET EMIDA, GOAT-TSE-FREE).

We declare no competing financial interests.

We thank the partners in the GoatBSE project for their contributions, especially the following providers of tissues and macerates: PierLuigi Acutis, IZSTO, Turin, Italy; Cristina Acin, UNIZAR, Zaragoza, Spain; and Frederic Lantier, INRA, Tours, France.

\section{REFERENCES}

1. Prusiner SB. 1991. Molecular biology of prion diseases. Science 252: 1515-1522. http://dx.doi.org/10.1126/science.1675487.

2. Baylis M, Chihota C, Stevenson E, Goldmann W, Smith A, Sivam K, Tongue S, Gravenor MB. 2004. Risk of scrapie in British sheep of different prion protein genotype. J. Gen. Virol. 85:2735-2740. http://dx.doi.org /10.1099/vir.0.79876-0.

3. Agrimi U, Conte M, Morelli L, Di Bari MA, Di Guardo G, Ligios C, Antonucci G, Aufiero GM, Pozzato N, Mutinelli F, Nonno R, Vaccari G. 2003. Animal transmissible spongiform encephalopathies and genetics. Vet. Res. Commun. 27(Suppl 1):31-38. http://dx.doi.org/10.1023/B:VERC.0000014115.18327.26.

4. Aguzzi A, Heikenwalder M, Polymenidou M. 2007. Insights into prion strains and neurotoxicity. Nat. Rev. Mol. Cell Biol. 8:552-561. http://dx .doi.org/10.1038/nrm2204.

5. Belt PB, Muileman IH, Schreuder BE, Bos-de Ruijter J, Gielkens AL, Smits MA. 1995. Identification of five allelic variants of the sheep PrP gene and their association with natural scrapie. J. Gen. Virol. 76:509-517. http: //dx.doi.org/10.1099/0022-1317-76-3-509.

6. Bossers A, Schreuder BE, Muileman IH, Belt PB, Smits MA. 1996. PrP genotype contributes to determining survival times of sheep with natural scrapie. J. Gen. Virol. 77:2669-2673. http://dx.doi.org/10.1099/0022-1317-77 $-10-2669$.

7. Hunter N. 1996. Prion protein (prnp) genotypes and natural scrapie in closed flocks of Cheviot and Suffolk sheep in Britain, p 47-50. In Court L, 
Dodet B (ed), Transmissible subacute spongiform encephalopathies: prion diseases. Elsevier, Paris, France.

8. Hunter N. 1997. PrP genetics in sheep and the applications for scrapie and BSE. Trends Microbiol. 5:331-334. http://dx.doi.org/10.1016 /S0966-842X(97)01081-0.

9. Dawson M, Hoinville LJ, Hosie BD, Hunter N. 1998. Guidance on the use of PrP genotyping as an aid to the control of clinical scrapie. Scrapie Information Group. Vet. Rec. 142:623-625.

10. Vaccari G, Panagiotidis CH, Acin C, Peletto S, Barillet F, Acutis P, Bossers A, Langeveld J, van Keulen L, Sklaviadis T, Badiola JJ, Andreeoletti O, Groschup MH, Agrimi U, Foster J, Goldmann W. 2009. State-of-the-art review of goat TSE in the European Union, with special emphasis on PRNP genetics and epidemiology. Vet. Res. 40:48. http://dx .doi.org/10.1051/vetres/2009031.

11. Fragkiadaki EG, Vaccari G, Ekateriniadou LV, Agrimi U, Giadinis ND, Chiappini B, Esposito E, Conte M, Nonno R. 2011. PRNP genetic variability and molecular typing of natural goat scrapie isolates in a high number of infected flocks. Vet. Res. 42:104. http://dx.doi.org/10.1186 /1297-9716-42-104.

12. Acin C, Martin-Burriel I, Monleon E, Lyahyai J, Pitarch JL, Serrano C, Monzon M, Zaragoza P, Badiola JJ. 2013. Prion protein gene variability in Spanish goats. Inference through susceptibility to classical scrapie strains and pathogenic distribution of peripheral $\operatorname{PrP}(\mathrm{sc}$.). PLoS One 8:e61118. http://dx.doi.org/10.1371/journal.pone.0061118.

13. Goldmann W, Chong A, Foster J, Hope J, Hunter N. 1998. The shortest known prion protein gene allele occurs in goats, has only three octapeptide repeats and is non-pathogenic. J. Gen. Virol. 79:3173-3176.

14. Benestad SL, Austbo L, Tranulis MA, Espenes A, Olsaker I. 2012. Healthy goats naturally devoid of prion protein. Vet. Res. 43:87. http://dx .doi.org/10.1186/1297-9716-43-87.

15. Barillet F, Mariat D, Amigues Y, Faugeras R, Caillat H, MoazamiGoudarzi K, Rupp R, Babilliot JM, Lacroux C, Lugan S, Schelcher F, Chartier C, Corbiere F, Andreoletti O, Perrin-Chauvineau C. 2009. Identification of seven haplotypes of the caprine PrP gene at codons 127, 142, 154, 211, 222 and 240 in French Alpine and Saanen breeds and their association with classical scrapie. J. Gen. Virol. 90:769-776. http://dx.doi .org/10.1099/vir.0.006114-0.

16. Gonzalez L, Martin S, Hawkins SA, Goldmann W, Jeffrey M, Siso S. 2010. Pathogenesis of natural goat scrapie: modulation by host PRNP genotype and effect of co-existent conditions. Vet. Res. 41:48. http://dx doi.org/10.1051/vetres/2010020.

17. Goldmann W, Ryan K, Stewart P, Parnham D, Xicohtencatl R, Fernandez N, Saunders G, Windl O, Gonzalez L, Bossers A, Foster J. 2011. Caprine prion gene polymorphisms are associated with decreased incidence of classical scrapie in goat herds in the United Kingdom. Vet. Res. 42:110. http://dx.doi.org/10.1186/1297-9716-42-110.

18. Goldmann W, Martin T, Foster J, Hughes S, Smith G, Hughes K, Dawson M, Hunter N. 1996. Novel polymorphisms in the caprine PrP gene: a codon 142 mutation associated with scrapie incubation period. J. Gen. Virol. 77: 2885-2891. http://dx.doi.org/10.1099/0022-1317-77-11-2885.

19. Billinis C, Panagiotidis CH, Psychas V, Argyroudis S, Nicolaou A, Leontides S, Papadopoulos O, Sklaviadis T. 2002. Prion protein gene polymorphisms in natural goat scrapie. J. Gen. Virol. 83:713-721. http: //vir.sgmjournals.org/content/83/3/713.long.

20. Bouzalas IG, Dovas CI, Banos G, Papanastasopoulou M, Kritas S, Oevermann A, Papakostaki D, Evangelia C, Papadopoulos O, Seuberlich T, Koptopoulos G. 2010. Caprine PRNP polymorphisms at codons 171, 211, 222 and 240 in a Greek herd and their association with classical scrapie. J. Gen. Virol. 91:1629-1634. http://dx.doi.org/10.1099/vir.0 .017350-0.

21. Colussi S, Vaccari G, Maurella C, Bona C, Lorenzetti R, Troiano P, Casalinuovo F, Di Sarno A, Maniaci MG, Zuccon F, Nonno R, Casalone C, Mazza M, Ru G, Caramelli M, Agrimi U, Acutis PL. 2008. Histidine at codon 154 of the prion protein gene is a risk factor for Nor98 scrapie in goats. J. Gen. Virol. 89:3173-3176. http://dx.doi.org/10.1099/vir.0.2008 1004150-0.

22. Papasavva-Stylianou P, Windl O, Saunders G, Mavrikiou P, Toumazos P, Kakoyiannis C. 2011. PrP gene polymorphisms in Cyprus goats and their association with resistance or susceptibility to natural scrapie. Vet. J. 187:245-250. http://dx.doi.org/10.1016/j.tvjl.2009.10.015

23. Acutis PL, Bossers A, Priem J, Riina MV, Peletto S, Mazza M, Casalone C, Forloni G, Ru G, Caramelli M. 2006. Identification of prion protein gene polymorphisms in goats from Italian scrapie outbreaks. J. Gen. Virol. 87:1029-1033. http://dx.doi.org/10.1099/vir.0.81440-0.

24. Vaccari G, Di Bari MA, Morelli L, Nonno R, Chiappini B, Antonucci G Marcon S, Esposito E, Fazzi P, Palazzini N, Troiano P, Petrella A, Di Guardo G, Agrimi U. 2006. Identification of an allelic variant of the goat PrP gene associated with resistance to scrapie. J. Gen. Virol. 87:1395-1402. http://dx.doi.org/10.1099/vir.0.81485-0.

25. Corbiere F, Perrin-Chauvineau C, Lacroux C, Costes P, Thomas M, Bremaud I, Martin S, Lugan S, Chartier C, Schelcher F, Barillet F, Andreoletti O. 2013. PrP-associated resistance to scrapie in five highly infected goat herds. J. Gen. Virol. 94:241-245. http://dx.doi.org/10.1099 /vir.0.047225-0.

26. Acutis PL, Martucci F, D’Angelo A, Peletto S, Colussi S, Maurella C, Porcario C, Iulini B, Mazza M, Dell'atti L, Zuccon F, Corona C, Martinelli N, Casalone C, Caramelli M, Lombardi G. 2012. Resistance to classical scrapie in experimentally challenged goats carrying mutation K222 of the prion protein gene. Vet. Res. 43:8. http://dx.doi.org/10.1186 /1297-9716-43-8.

27. Lacroux C, Perrin-Chauvineau C, Corbière F, Aron N, Aguilar-Calvo P, Torres JM, Costes P, Brémaud I, Lugan S, Schelcher F, Barillet F, Andréoletti O. 2014. Genetic resistance to scrapie infection in experimentally challenged goats. J. Virol. 88:2406-2413. http://dx.doi.org/10.1128 /JVI.02872-13.

28. Castilla J, Gutierrez-Adan A, Brun A, Doyle D, Pintado B, Ramirez MA, Salguero FJ, Parra B, Diaz San Segundo F, Sanchez-Vizcaino JM, Rogers M, Torres JM. 2004. Subclinical bovine spongiform encephalopathy infection in transgenic mice expressing porcine prion protein. J. Neurosci. 24: 5063-5069. http://dx.doi.org/10.1523/JNEUROSCI.5400-03.2004

29. Borchelt DR, Davis J, Fischer M, Lee MK, Slunt HH, Ratovitsky T, Regard J, Copeland NG, Jenkins NA, Sisodia SS, Price DL. 1996. A vector for expressing foreign genes in the brains and hearts of transgenic mice. Genet. Anal. 13:159163. http://dx.doi.org/10.1016/S1050-3862(96)00167-2.

30. Fink PS. 1991. Using sodium chloride step gradients to fractionate DNA fragments. Biotechniques 10:446, 448, 450.

31. Manson JC, Clarke AR, Hooper ML, Aitchison L, McConnell I, Hope J. 1994. 129/Ola mice carrying a null mutation in PrP that abolishes mRNA production are developmentally normal. Mol. Neurobiol. 8:121-127. http://dx.doi.org/10.1007/BF02780662.

32. Foster JD, Wilson M, Hunter N. 1996. Immunolocalisation of the prion protein (PrP) in the brains of sheep with scrapie. Vet. Rec. 139:512-515. http://dx.doi.org/10.1136/vr.139.21.512.

33. Langeveld JP, Jacobs JG, Erkens JH, Bossers A, van Zijderveld FG, van Keulen LJ. 2006. Rapid and discriminatory diagnosis of scrapie and BSE in retro-pharyngeal lymph nodes of sheep. BMC Vet. Res. 2:19. http://dx.doi .org/10.1186/1746-6148-2-19.

34. Padilla D, Béringue V, Espinosa JC, Andreoletti O, Jaumain E, Reine F, Herzog L, Gutierrez-Adan A, Pintado B, Laude H, Torres JM. 2011. Sheep and goat BSE propagate more efficiently than cattle BSE in human PrP transgenic mice. PLoS Pathog. 7:e1001319. http://dx.doi.org/10.1371 /journal.ppat.1001319.

35. Feraudet C, Morel N, Simon S, Volland H, Frobert Y, Creminon C, Vilette D, Lehmann S, Grassi J. 2005. Screening of 145 anti-PrP monoclonal antibodies for their capacity to inhibit PrPSc replication in infected cells. J. Biol. Chem. 280: 11247-11258. http://dx.doi.org/10.1074/jbc.M407006200.

36. Andreoletti O, Lacroux C, Chabert A, Monnereau L, Tabouret G, Lantier F, Berthon P, Eychenne F, Lafond-Benestad S, Elsen JM, Schelcher F. 2002. $\operatorname{PrP}(\mathrm{Sc})$ accumulation in placentas of ewes exposed to natural scrapie: influence of foetal PrP genotype and effect on eweto-lamb transmission. J. Gen. Virol. 83:2607-2616. http://vir .sgmjournals.org/content/83/10/2607.long.

37. Fraser H, Dickinson AG. 1968. The sequential development of the brain lesion of scrapie in three strains of mice. J. Comp. Pathol. 78:301-311. http://dx.doi.org/10.1016/0021-9975(68)90006-6.

38. Andreoletti O, Berthon P, Levavasseur E, Marc D, Lantier F, Monks E, Elsen JM, Schelcher F. 2002. Phenotyping of protein-prion (PrPsc)-accumulating cells in lymphoid and neural tissues of naturally scrapie-affected sheep by doublelabeling immunohistochemistry. J. Histochem. Cytochem. 50:1357-1370. http: //dx.doi.org/10.1177/002215540205001009.

39. Andreoletti O, Simon S, Lacroux C, Morel N, Tabouret G, Chabert A, Lugan S, Corbiere F, Ferre P, Foucras G, Laude H, Eychenne F, Grassi J, Schelcher F. 2004. $\operatorname{PrP}(\mathrm{Sc})$ accumulation in myocytes from sheep incubating natural scrapie. Nat. Med. 10:591-593. http://dx.doi.org/10 $.1038 / \mathrm{nm} 1055$. 
40. Foster JD, Hope J, Fraser H. 1993. Transmission of bovine spongiform encephalopathy to sheep and goats. Vet. Rec. 133:339-341. http://dx.doi .org/10.1136/vr.133.14.339.

41. Kobayashi A, Hizume M, Teruya K, Mohri S, Kitamoto T. 2009. Heterozygous inhibition in prion infection: the stone fence model. Prion 3:27-30. http://dx.doi.org/10.4161/pri.3.1.8514.

42. Shibuya S, Higuchi J, Shin RW, Tateishi J, Kitamoto T. 1998. Codon 219 Lys allele of PRNP is not found in sporadic Creutzfeldt-Jakob disease. Ann. Neurol. 43:826-828. http://dx.doi.org/10.1002/ana 410430618

43. Lee CI, Yang Q, Perrier V, Baskakov IV. 2007. The dominant- negative effect of the $\mathrm{Q} 218 \mathrm{~K}$ variant of the prion protein does not require protein X. Protein Sci. 16:2166-2173. http://dx.doi.org/10 $.1110 /$ ps.072954607.

44. Eiden M, Soto EO, Mettenleiter TC, Groschup MH. 2011. Effects of polymorphisms in ovine and caprine prion protein alleles on cell-free conversion. Vet. Res. 42:30. http://dx.doi.org/10.1186/1297-9716-42-30.

45. Espinosa JC, Andreoletti O, Castilla J, Herva ME, Morales M, Alamillo E, San-Segundo FD, Lacroux C, Lugan S, Salguero FJ, Langeveld J, Torres JM. 2007. Sheep-passaged bovine spongiform encephalopathy agent exhibits altered pathobiological properties in bovine-PrP transgenic mice. J. Virol. 81:835-843. http://dx.doi.org/10.1128/JVI.01356-06. 